\title{
Verification of the reflective model of first order factors for reward and empowerment constructs, based on questionnaires derived from Lawler et al. (1991)
}

\author{
Juan A. Marin-Garcia, Graziela Conci \\ Universidad Politécnica de Valencia (Spain) \\ jamarin@,omp.upv.es,graziconci@yahoo.com.br
}

Received: January 2012

Accepted: November 2012

\section{Abstract:}

Purpose: High involvement practices have traditionally been classified in four main categories: training, communication, rewards and empowerment. In order to measure the degree of implementation of these programs, different questionnaires have been developed. In this paper, we have identified 3 types of questionnaires and we have deeply analyzed the psychometrical properties of one of these types: questionnaires derived from Lawler et al. (1991). The most recent investigation seems to show that psychometrical properties of both training and communication constructs are appropriate. However, it is necessary to work on rewards and empowerment scales. This research analyzes, by means of confirmatory factorial, two reflective measurement models, already present in the previous literature of rewards and empowerment scales.

Design/methodology/approach: Spanish samples from 1997 ( $\mathrm{n}=105)$, as well as United States ones ( $\mathrm{n}=212$ dating 1996 and $\mathrm{n}=143$ dating 1999) have been used. Convergent and discriminant validity were tested.

Findings and Originality/value: None of the models presents and acceptable adjustment in the used samples. Therefore, a possible future line of investigation in order to check whether the measurement model of rewards and empowerment constructs is formative instead of reflective, has been opened. 
Practical implications: Practitioners can profit from the results of this research because questionnaires validity will allow companies to have measurement and good practices diagnosis tools that can be used either for internal benchmarking or for the comparison with reference groups of companies.

Originality/value: our paper identifies three questionnaire typologies used in the field of investigations of rewards and empowerment practices. We show that the point of view with which the scales of theses questionnaires have been treated has always been reflective. Moreover, this is one of the few papers that have checked the validity of the measurement model of questionnaires derived from Lawler et al. (1991). It questions the validity of a single questionnaire with similar samples, of different years, and simultaneously, with samples from same years but from different countries.

Keywords: HIWP; Human Resource Management practices; High Involvement; Rewards; Empowerment

\section{Introduction}

In the last years there have been plenty of different researches in the area of Human Resources Management (HMR). These studies have allowed this discipline to advance and at the same time, have dealed with interesting questions for both academicians and professionals. For instance, the relationship between the human resources management and the company performance indicators (Guthrie, 2001; Huselid, 1995; Ichniowski \& Shaw, 1999; MacDuffie, 1995; Wood, 1999; Benson, Young \& Lawler III, 2006; Alliger, Tannembaum, Bennett, Traver \& Shotland, 1997; Cohen, 1993; Combs, Liu, Hall \& Ketchen, 2006; Guest, 1997; Wood \& de Menezes, 2008; Lopez-Araujo, Segovia \& Peiro, 2007; Addison, 2005; Guerrero \& Barraud-Didier, 2004); the determination of the ways in which human resources management systems affect the company results, and the unraveling of the "black box" between the use of practices and results (Guthrie, Flood, Liu \& MacCurtain, 2009; Katou, 2008; Becker \& Huselid, 2006); the identification of particularities, difficulties and advantages for the use of such practices in either small, public sector or new creation companies Cunningham, 2007 CUNNINGHAM2007 /id;Brown, 2007 BROWN2007 /id;Ciavarella, 2004 2223 /id\}; the maintenance of these practices (Cox, Zagelmeyer \& Marchington, 2006; Gollan, 2006), or the specification of human resources management practices as a latent construct (Murphy, DiPietro \& Murrmann, 2007; de Menezes \& Lasaosa, 2007; Williams \& O'Boyle, 2008; Boxall \& Macky, 2009; Marin-Garcia \& Conci, 2009; Lin, 2006; Long \& Shields, 2005). However, many of these questions still do not have a conclusive answer (Delery, 1998; 
Verburg, Den Hartog \& Koopman, 2007; Boxall \& Macky, 2009; Katou, 2008; Becker \& Huselid, 2006; Gerhart, Wright, Mahan \& Snell, 2000).

In the investigation about human resources practices, it is common to use a multi-item questionnaire in order to measure the practices establishment degree. Therefore the specification of the measurement model would be requested. Moreover, this is an indispensable condition for the replica of studies or for the comparison between the researches done by different authors (Geyskens, Krishnan, Steenkamp \& Cunha, 2009; Slavin, 1986; Hunter, Schmidt \& Jackson, 1982). Nevertheless, in most of the papers, measurement models of human resources management practices, and in particular those of high- involvement practices (HIWP), are not openly specified (Wong, Law \& Huang, 2008; Wood \& de Menezes, 2008). In this sense, there is still the necessity of clarifying human resources management practices within the constructs in order, for instance, to compare the results derived from different studies (Katou, 2008; Boxall \& Macky, 2009). Related to the previous, the use of different answer levels (dichotomy, interval, constant) as well as the way of measuring variables may condition the results. Therefore a deeper research would be required (Verburg et al., 2007). Finally, it is required to analyze the relationship between high-involvement practices themselves and to define whether they are complementary, substitutive, they reinforce themselves or whether they simply show a higher level orientation or construct (Verburg et al., 2007; Delery, 1998; Wood \& de Menezes, 2008).

The published researches have used three types of questionnaires. Amongst them, two types have been more frequently used. Since the approach and questions of each one is very different from the others, thus not being comparable, we are going to focus ourselves in the study of the first type measurement model (papers based on the original questionnaire of Lawler III (1991)). On the one hand, this is one of the most common and most used questionnaires. It is odd to observe that the other kind of questionnaires have been intentionally created for each single research and, just rarely, they have been reused by other researchers. This makes the interpretation and the comparison of the results between different studies difficult. Besides, questionnaires based on the original questionnaire of Lawler III (1991) give rise to a construct model without specification. Therefore, it is not clear whether they should be regarded either as reflective or formative.

A previous research (authors cite1) has proved that both communication and training constructs show a great adjustment whenever they are regarded as reflective measurement model. Yet, it is still required to work with rewards and empowerment scales, for some of the obtained results make us doubt about their supposed single dimension (authors cite2).

On the other hand, in previous HIWP investigations (High Involvement Work Practices) it is not usual to find the measurement model validation due to the fact that most of the papers are focused in testing structure models. It is even odder to find studies that validate 
measurement models in different samples, for most of the authors build their own questionnaire, which is not further used in other investigations.

Our investigation will be focused on proving if we can validate first level reflective measurement models in both rewards and empowerment scales. Using a confirmatory factorial analyses, we will also check two models based on the literature (Lawler III, Mohrman, \& Ledford, 1998; Wood \& de Menezes, 2008). For this purpose, we will use data coming from both Spanish (1997) and USA samples (1996 and 1999).

\section{Theoretical Frame}

In academic literature, high-involvement practices (HIWP) have received the following names: high-involvement work practices, high-performance work practices, high-commitment work practices (Guthrie, Spell \& Nyamori, 2002; Melian-Gonzalez \& Verano-Tacorante, 2004; Lawler III, 1991; Lawler III, 2005; Bayo Moriones \& Merino Díaz de Cerio, 2002). In general, all these terms may be considered as synonyms (Melian-Gonzalez \& Verano-Tacorante, 2004), and they represent a system of practices that give the employees the skills, information and motivation to participate in the decision-making. As a result, they transform the work force in a source of sustainable and competitive advantage, whenever related practices are used along with the company strategy (Mayson \& Barrett, 2006; Guthrie et al., 2002; Guerrero \& Barraud-Didier, 2004; Zatzick \& Iverson, 2006; Wood \& de Menezes, 2008). Furthermore, this kind of programs build a coherent, consistent and reinforced system, in such a way that the global result is higher than the isolated application of any of the practices (Drummond \& Stone, 2007).

Depending on the reference author, the list of practices is more or less wide. However, it seems to be a consensus in order to group them in different categories. Most commonly quoted categories match up with those proposed by Lawler III (1991): training, communication, empowerment and rewards (Guerrero \& Barraud-Didier, 2004; Lin, 2006; Combs et al., 2006; Zatzick \& Iverson, 2006). Together with them, some researchers have included other categories such as personnel selection innovative practices, performance evaluation and internal promotion (Camelo, Martin, Romero, \& Valle, 2004; Wood \& de Menezes, 2008; Drummond \& Stone, 2007). Nevertheless, only the four original categories (Table 1) have been borne in mind by almost all the authors that have done research into this subject, as high-involvement ones (Guerrero \& Barraud-Didier, 2004; Wood \& de Menezes, 2008).

The first order measurement model for "communication" and "training" constructs, has been validated in a previous work of the authors (authors cite 1 ). Convergent validity test were acceptable (normed chi2 <5; CFI,IFI,MFI,GFI>0.90, Cronbach $\alpha>0.77$; Compound 
Reliability $>0.77$ Extracted Variance $>0.40$ ). Therefore in this paper we are going to focus on rewards and empowerment practices.

\begin{tabular}{|l|l|}
\hline \multicolumn{1}{|c|}{ Construct } & \multicolumn{1}{c|}{ Definition } \\
\hline Communication & $\begin{array}{l}\text { Type of information which is usually shared with the operators so that they can participate in the } \\
\text { decisions related either to the success of their field of work or to that of the company s. }\end{array}$ \\
\hline Training & $\begin{array}{l}\text { Systematic and formal training offered to operators in the last three years, and in different skills for } \\
\text { the commitment of the workers and for the development of systems such as the global quality } \\
\text { management or similar ones. }\end{array}$ \\
\hline Rewards & Use of programs or reward systems that tend to support the involvement of operators. \\
\hline Empowerment & $\begin{array}{l}\text { Programs or organizational changes that allow to shift the decision-making or the power towards } \\
\text { the workers. }\end{array}$ \\
\hline
\end{tabular}

Table 1. Categories that make up high-involvement practices (Lawler III, 1991; Lawler III et al., 1998)

In order to measure the degree of use of high-involvement practices related to rewards and empowerment, different questionnaires have been used.

Some authors (Marin-Garcia, 2002; Coye \& Belohlav, 1995; Guerrero \& Barraud-Didier, 2004; Marin-Garcia, Bonavia \& Miralles Insa, 2008; Benson et al., 2006; Lawler III, 2005; Yu, Finegold, Lawler III \& Cochran, 2000) use a questionnaire derived from that of Lawler et al. (1991). In these, from now on we will call them Type A, the degree of use of different highinvolvement programs is questioned. All programs are mostly the same in these researches. Each question is answered in 5 o 7 levels, depending on the percentage of employees that take part in such programs $(0 \% ; 1-20 \% ; \ldots ; 81-99 \% ; 100 \%)$. These items are grouped either in 2 constructs (rewards and empowerment) or in 4 (performance reward systems, employee involvement supportive rewards systems, parallel power sharing and work redesign practices). In Table 2 we describe the structure of these constructs. Models $1 \mathrm{a}$ and $1 \mathrm{~b}$ include all rewards and empowerment items in a single factor, whereas models $2 a, 2 b, 2 c$ and $2 d$ divide their items in two rewards and two empowerment dimensions (Lawler III et al., 1998). All of them represent first order models. Alternative models where the two dimensions of each of the 2 models would be grouped in a second order factor, could also be considered. However, in such a case, it would be necessary that models $2 a, 2 b, 2 c$ and $2 d$ had a good fit.

Within this type A we can also include those studies which ask for the degree of use of programs, even though they only ask about a small part of the programs in table 2 (and not always about the same) or even the answer levels are either dichotomy scales (use/do not use or yes/no) or a likert scale with 5 or more answer levels (from "not implemented/totally disagree" to "completely implemented/totally agree") (Melian-Gonzalez \& Verano-Tacorante, 2004; Zatzick \& Iverson, 2006; Barrett \& Mayson, 2007; Zacharatos, Barling, \& Iverson, 2005; Yang, 2006; Datta, Guthrie, \& Wright, 2005; Bou \& Beltran, 2005; Combs et al., 2006; Wood, Holman \& Stride, 2006; Wood \& de Menezes, 2008; Guthrie et al., 2009). 


\begin{tabular}{|c|c|c|c|}
\hline Models 1 & Models 2 & Questionnaire question & Code \\
\hline \multirow[t]{9}{*}{$\begin{array}{l}\text { Rewards } \\
\text { (Model 1a) }\end{array}$} & \multirow{3}{*}{$\begin{array}{l}\text { Employee } \\
\text { involvement } \\
\text { supportive } \\
\text { rewards } \\
\text { systems- } \\
\text { (Model 2a) }\end{array}$} & $\begin{array}{l}\text { Complements for skills or knowledge: the employee earns the } \\
\text { basic wage plus an additional quantity depending on the } \\
\text { amount of different posts he/she can perform or on his/her } \\
\text { level of training. }\end{array}$ & Rem2 \\
\hline & & $\begin{array}{l}\text { Flexible remuneration: the employee decides how he/she wants } \\
\text { to receive the salary. Common alternatives are: in cash, by } \\
\text { means of training courses, travels, social benefits, additional } \\
\text { holidays...The worker does not decide his/her salary, but has } \\
\text { got full autonomy to decide how to receive it. }\end{array}$ & Rem9 \\
\hline & & $\begin{array}{l}\text { Employment security: company policy or special clauses in } \\
\text { contracts to avoid dismissals. }\end{array}$ & Rem 10 \\
\hline & \multirow{6}{*}{$\begin{array}{l}\text { Performance } \\
\text { reward } \\
\text { systems- } \\
\text { (Model 2b) }\end{array}$} & $\begin{array}{l}\text { Share-out of company benefits: distribution of a part of the } \\
\text { company benefits between the employees. }\end{array}$ & Rem3 \\
\hline & & $\begin{array}{l}\text { Share-out of gains coming from suggestions (Gain sharing, } \\
\text { Scanlon...): a part of the savings or the gains in productivity, } \\
\text { quality, or costs stemming from the suggestion of an employee } \\
\text { or group of employees, is shared between those who made that } \\
\text { proposal. }\end{array}$ & Rem4 \\
\hline & & $\begin{array}{l}\text { Complement for the achievement of individual goals: an } \\
\text { additional quantity is added to the basic wage for the obtaining } \\
\text { of some short or long-term objectives or goals. }\end{array}$ & Rem5 \\
\hline & & $\begin{array}{l}\text { Complement for the achievement of group goals: an additional } \\
\text { quantity is added to the basic wage of the operators of a group } \\
\text { once they have achieved the group objectives or goals.. }\end{array}$ & Rem6 \\
\hline & & $\begin{array}{l}\text { Non-Economic rewards linked to performance: Greetings, } \\
\text { company rewards, employee of the year... }\end{array}$ & Rem7 \\
\hline & & $\begin{array}{l}\text { Participation in the company capital: the employee receives as } \\
\text { a part of the salary a certain amount of shares or participations } \\
\text { in the company capital. }\end{array}$ & Rem8 \\
\hline \multirow[t]{7}{*}{$\begin{array}{l}\text { Empowerm } \\
\text { ent (Model } \\
\text { 1b) }\end{array}$} & \multirow{4}{*}{$\begin{array}{l}\text { Parallel } \\
\text { power } \\
\text { sharing } \\
\text { (Model 2c) }\end{array}$} & $\begin{array}{l}\text { Individual proposals: procedures that encourage employees to } \\
\text { propose suggestions to improve the process or the labor } \\
\text { environment. }\end{array}$ & Part1 \\
\hline & & $\begin{array}{l}\text { Opinion polls: the company gathers motivation, satisfaction, } \\
\text { necessities, or training levels as well as employee expectations } \\
\text { data }\end{array}$ & Part2 \\
\hline & & $\begin{array}{l}\text { Opinion polls: the company gathers motivation, satisfaction, } \\
\text { necessities, or training levels as well as employee expectations } \\
\text { data }\end{array}$ & Part4 \\
\hline & & $\begin{array}{l}\text { Alternative groups to the quality circles: groups to propose } \\
\text { suggestions. They can be formed by staff from different } \\
\text { departments or levels of leadership, as well as with wider fields } \\
\text { of work than those of the quality circles. }\end{array}$ & Part5 \\
\hline & \multirow[t]{3}{*}{$\begin{array}{l}\text { Work } \\
\text { redesign } \\
\text { practices - } \\
\text { (Model 2d) }\end{array}$} & $\begin{array}{l}\text { Enrichment or redefinition of job positions: the company } \\
\text { modifies the characteristics of job posts in order to increase } \\
\text { productivity and employee satisfaction, thus adding a wider } \\
\text { variety of tasks, autonomy, self-identity with the tasks, } \\
\text { responsibility, sense, more versatile tasks. }\end{array}$ & Part3 \\
\hline & & $\begin{array}{l}\text { Autonomous or half-autonomous groups of work: they are also } \\
\text { called teams of work, The group is responsible of the product or } \\
\text { of a part of it, with a high autonomy level in the operative } \\
\text { decisions assumed by the own employees. }\end{array}$ & Part8 \\
\hline & & $\begin{array}{l}\text { Mini-companies: a part of the company works as an } \\
\text { independent business unit, creating its own goods or services } \\
\text { and with a high degree of autonomy. }\end{array}$ & Part7 \\
\hline
\end{tabular}

Table 2. Rewards and Empowerment Constructs and dimensions in Type A questionnaires (Lawler III et

$$
\text { al., 1998) }
$$

In table 3 we introduce some question examples the way they are formulated in Type A questionnaires.

Some other studies use questionnaires which include questions about conducts or behaviours within the company. These are usually answered showing the frequency with which such behaviours or conducts occur in 5 or more levels (from totally agree to totally disagree) 
(Schroeder \& Flynn, 2001; Kaya, 2006; Vandenberg, Richardson, \& .Eastman, 1999; Bayo Moriones \& Merino Díaz de Cerio, 2002; Ooi, Arumugam, Safa, \& Bakar, 2007; Wood, Stride, Wall, \& Clegg C.W., 2004). We will designate these kind of questionnaires Type B ones. A variant of these questionnaires also uses 3-5 answer levels (from beginner to expert) which describe the characteristics that should be fulfilled in order to mark each of the levels (Jackson \& Dyer, 1998). These questionnaires have principally a reflective focus in their item approach.

\begin{tabular}{|l|l|l|}
\hline Author & Questions & Answer levels \\
\hline (Barrett \& Mayson, 2007) & $\begin{array}{l}\text { As an employer do you offer bonuses or } \\
\text { incentives to reward } \\
\text { performance? }\end{array}$ & Yes/No \\
\hline (Guthrie et al., 2009) & $\begin{array}{l}\text { What proportion of your employees are } \\
\text { involved in programs designed to elicit } \\
\text { participation and employee input (e.g., } \\
\text { quality circles, problem-solving or similar } \\
\text { groups)? }\end{array}$ & $\begin{array}{l}\text { Five-point Likert scales } \\
\text { The article does not describe } \\
\text { the scales. }\end{array}$ \\
\hline (Lawler III et al., 1998) & $\begin{array}{l}\text { About how many employees are covered } \\
\text { by or are eligible for a pay/reward } \\
\text { system with all-salaried pay systems? }\end{array}$ & $\begin{array}{l}\text { Seven-point Likert scales } \\
(0 \% ; 1-20 \% ; \ldots ; 81-99 \% ; \\
100 \%)\end{array}$ \\
\hline (Lawler III et al., 1998) & $\begin{array}{l}\text { About how many of your corporation's } \\
\text { employees are currently involved } \\
\text { Suggestion system programs? }\end{array}$ & $\begin{array}{l}\text { Seven-point Likert scales } \\
(0 \% ; 1-20 \% ; . . . ; 81-99 \% ; \\
100 \%)\end{array}$ \\
\hline
\end{tabular}

Table 3. Question samples from type A questionnaires

In table 4 we introduce some question examples from type B questionnaires.

\begin{tabular}{|l|l|l|}
\hline Author & Questions & Answer Levels \\
\hline (Kaya, 2006) & $\begin{array}{l}\text { Our reward system really recognizes the } \\
\text { people who contribute the most to our } \\
\text { firm }\end{array}$ & $\begin{array}{l}\text { Five-point Likert scales } \\
1 \text { Totally disagree...5 Totally } \\
\text { agree }\end{array}$ \\
\hline $\begin{array}{l}\text { (Vandenberg et al., } \\
1999)\end{array}$ & $\begin{array}{l}\text { For the most part I am encouraged to } \\
\text { participate in and make decisions that } \\
\text { affect day-to-day activities }\end{array}$ & $\begin{array}{l}\text { Four-point Likert scales } \\
\text { The article does not describe } \\
\text { the scales. }\end{array}$ \\
\hline
\end{tabular}

Tabla 4. Question samples from type B questionnaires

Finally, we have just found a single publication (Lawler III et al., 1998) where the questionnaire has been organised following a level of profiles grouped in different exclusive categories. These categories denote either different approaches or different degree of development of high-involvement practices, and the polled chooses to place himself or herself in one of the focuses. For us, this would be Type $\mathrm{C}$. In table 5 a Type $\mathrm{C}$ questionnaire sample is introduced. Other authors(Appelbaum \& Batt, 1994; Macy \& Izumi, 1993; Ichniowski \& Shaw, 1999; Wood \& de Menezes, 2008) follow an alternative procedure and make different questions (similar to those of type A questionnaires) in order to, afterwards, group the companies in clusters depending on their profile resemblance.

From these three types of questionnaires, the two first ones (Type A and Type B) are those most frequently used. Type $B$ questionnaires, even though they do not clearly state constructs model, they present some item types that make us think about a latent reflective model. However, Type A questionnaires give rise to non specific construct model. Therefore, they could be regarded either as reflective or formative. In spite of this possible double nature, all 
reference studies consider empowerment and rewards scales as reflective ones (Wood \& de Menezes, 2008). Not a single study has made this evaluation obvious. Nevertheless, all of them inform about Cronbach $\alpha$ (table 6 ), or about the results of the exploratory factorial analysis with main components as the scale reliability. This is the irrefutable sign that the scales arte being viewed as reflective (Roberts \& Hirsch, 2005).

Approximately what percent of your corporation's employees are in units in which each of the following patterns of employee involvement practice is predominant? Please allocate $100 \%$ in answering 1-5.

1. None. No significant employee involvement exists in these parts of the corporation

2. Improvement Teams. Employee involvement focuses on special groups that are responsible for recommending improvements to management. These groups may be participation groups, quality circles...

3. Job involvement. Employee involvement focuses on creating work designs that are highly motivating, such as self-managing teams. Training focuses on job specific skills and/or team functioning...

4. Business involvement. Employees are involved heavily in the management of the business. Improvement teams and job involvement approaches may be used as part of this strategy...

5. Other form of involvement. Employee involvement approaches not described by 2,3 or 4 .

Table 5. Question samples from type C questionnaires (Lawler III et al., 1998)

\begin{tabular}{|l|r|r|r|r|r|r|r|r|}
\hline Categories & \multicolumn{2}{l|}{$\begin{array}{l}\text { (Benson et al., } \\
\text { 2006) }\end{array}$} & \multicolumn{2}{l|}{$\begin{array}{l}\text { Coye \& } \\
\text { Belohlav, } \\
1995)\end{array}$} & \multicolumn{2}{l|}{$\begin{array}{l}\text { Guerrero \& } \\
\text { Barraud-Didier, } \\
\text { 2004) }\end{array}$} & \multicolumn{2}{l|}{ (authors cite 1) } \\
\hline & Ítems & Alpha & Ítems & Alpha & Ítems & Alpha & Ítems & Alpha \\
\hline Empowerment & 7 & 0.71 & 4 & 0.62 & 5 & 0.83 & 8 & 0.74 \\
\hline Rewards & 2 & 0.60 & 3 & 0.51 & 3 & 0.81 & 9 & 0.65 \\
\hline
\end{tabular}

Tabla 6. Scale validation of type A questionnaires

\section{Goals}

In spite of the general supposition that Type A questionnaires rewards and empowerment scales are reflective, the measurement model has only been validated after confirmatory factorial analysis in one single paper (Yu et al., 2000). In it, we can observe that the used measurement model does not show a proper adjustment of the gathered data from different USA companies, where it is difficult to consider empowerment and rewards constructs as single dimensioned, and even more complicated to consider a second order latent factor that represents HIWP. However, it seems that in the sample from China, both rewards and empowerment are well adjusted as single dimension constructs (the factorial charges of the items in each dimension are significant, and most of them above 0.60 ).

In this research, in which we join ourselves to the traditional interpretation of scales as reflective, we can propose different first order measurement models (figures 1 to 6 ). Models $1 \mathrm{a}$ and $1 \mathrm{~b}$ associate all rewards items to a factor and those of empowerment to another one (Coye \& Belohlav, 1995; Guerrero \& Barraud-Didier, 2004; Benson et al., 2006; Yu et al., 2000). Models 2a, 2b, 2c and 2d create two first order factors, both for rewards as for empowerment, following the structure in table 2 (Lawler III et al., 1998). 


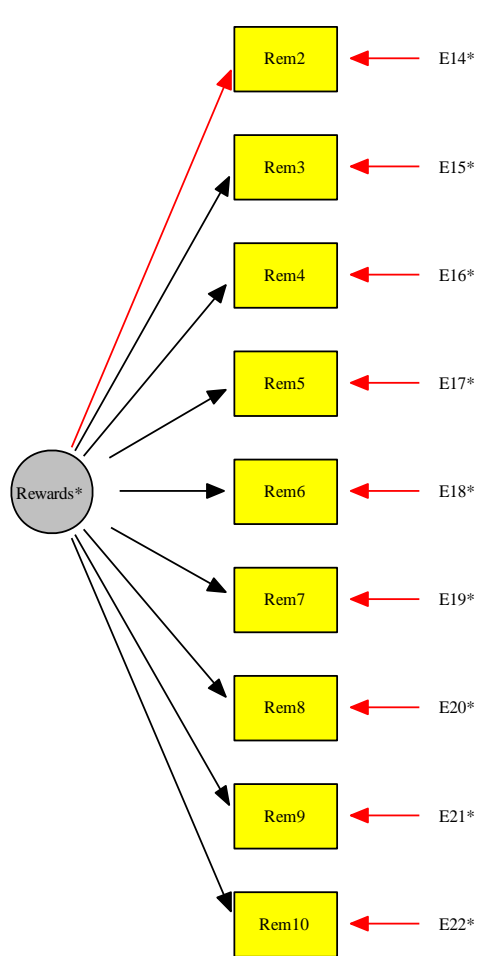

Figure 1. Model 1a - Rewards
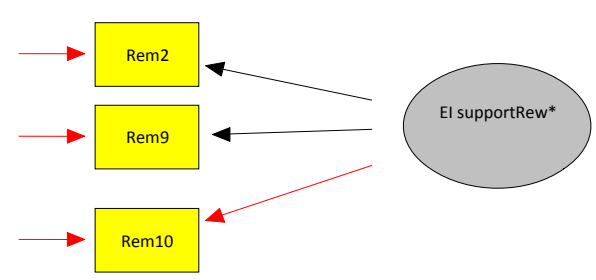

Figure 3. Model 2a - Rewards

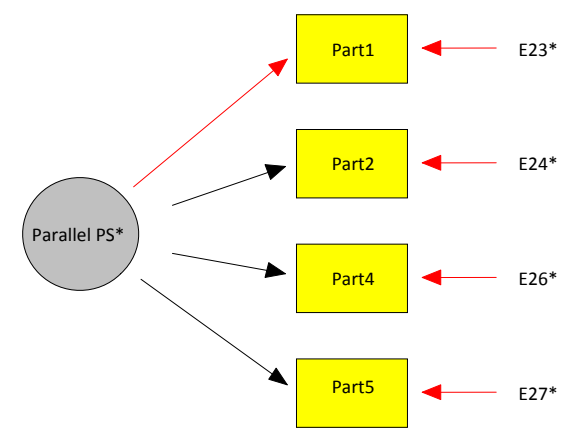

Figure 5. Model 2c- Empowerment

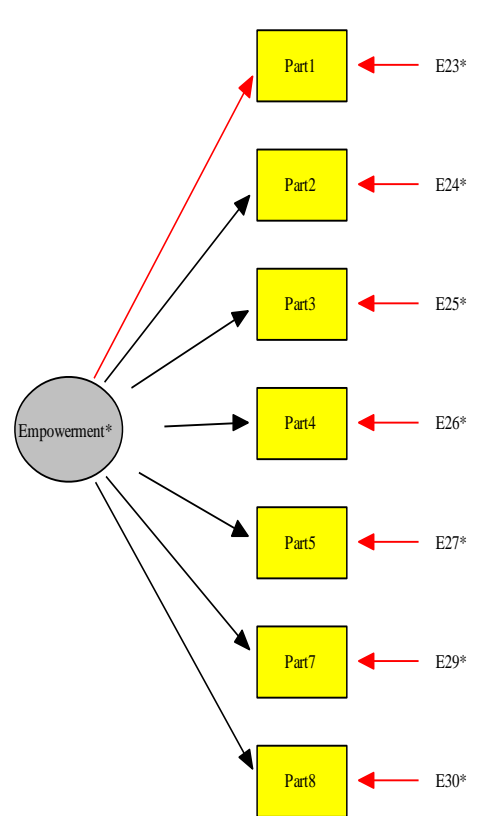

Figure 2. Model 1b - Empowerment

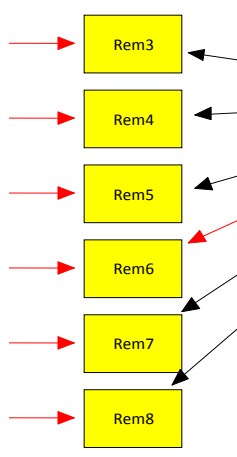

Figure 4. Model 2b-Rewards

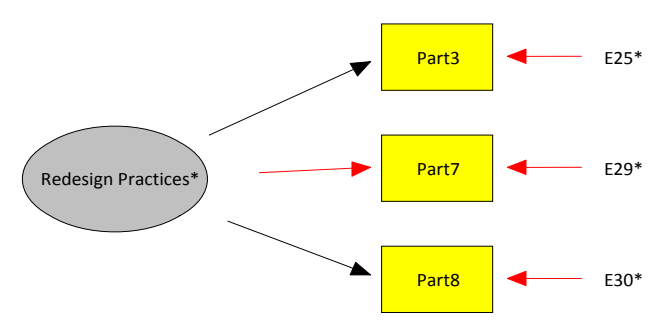

Figure 6. Model 2d - Empowerment 
The goals of our research are:

- Verify whether any of the proposed measurement models is validated by a confirmatory analysis of data coming from different countries and years samples.

- Provided the previous objective is not fulfilled, propose a measurement model for rewards and empowerment constructs.

\section{Methodology}

The measurement model has taken into account that each indicator is linked to a single construct and we will use a confirmatory modelization strategy. In this strategy we stem from a single model where every relationship is clearly established, and we check whether the model adjusts to data (Hair, Anderson, Tatham \& Black, 1999). In first instance, we have verified the significance of all the factorial charges of the indicators that compose the scale, whose values should be above 0.6 (Hair et al., 1999; Bagozzi, 1994). Convergent validity has been checked by using four different criterions. The first of them is that, at least 4 amongst the 7 goodness fit statistics of the model are appropriate (table 7). In second place, we have verified whether compound internal reliability is above 0.7 (Hair et al., 1999). In third instance we have verified that Cronbach $\alpha$ values are above 0.7 (Lin, 2006; Hair et al., 1999; Tari, Molina \& Castejón, 2007), and as a fourth criterion we have contrasted whether the extracted variance is above $40 \%$ (Hair et al., 1999). We will assume that the proposed measurement models have convergent validity whenever they fulfill two or more of these four criterions.

We have checked the discriminant validity by means of the test of the extracted variance versus the squared correlations (Fornell \& Larcker, 1981), as well as by the correlations confidence interval (Anderson \& Gerbing, 1988).

The analyses have been executed with the method of maximum verisimilitude of the EQS program (Bentler, 2002; Ullman \& Bentler, 2004).

\begin{tabular}{|l|l|l|l|l|l|l|}
\hline $\begin{array}{l}\text { Chi2 } \\
\text { significance }\end{array}$ & $\begin{array}{l}\text { Chi2/Degree } \\
\text { of Freedom }\end{array}$ & $\begin{array}{l}\text { Comparative } \\
\text { fit index CFI }\end{array}$ & $\begin{array}{l}\text { Bollen Fit } \\
\text { index } \\
\text { IFI }\end{array}$ & $\begin{array}{l}\text { McDolland } \\
\text { Fit index } \\
\text { MFI }\end{array}$ & $\begin{array}{l}\text { Lisrel Fit } \\
\text { Index } \\
\text { GFI }\end{array}$ & $\begin{array}{l}\text { Root mean square } \\
\text { error of } \\
\text { appproximation } \\
\text { RMSEA }\end{array}$ \\
\hline $\begin{array}{l}>0.05 \text { (safer } \\
\text { if above 0.1) }\end{array}$ & $\begin{array}{l}<3 \text { (maximum } \\
\text { reach 5) }\end{array}$ & $>0.90$ & $>0.90$ & $>0.90$ & $>0.85$ & $\begin{array}{l}<0.08 \text { (maximum } \\
\text { reach 0.10) }\end{array}$ \\
\hline
\end{tabular}

Table 7. Suitable values for satisfactory adjustment of the model (Tari et al., 2007; Sila, 2007; Hair, Anderson, Tatham, \& Black, 1995; Ullman \& Bentler, 2004; Spreitzer, 1995)

If any of the predicted models were note validated by the confirmatory factorial analyses, and in order to propose an alternative measurement model to the traditional one, we would use the exploratory factorial analyses with the method of main components and maximum verisimilitude, as well as factors extraction with eigen values above 1 and varimax Kaiser orthogonal rotation. For the assignment of items to factors, we use the criterion that the 
factorial loads are above 0.3 in a single factor, and that the difference between loads of the assigned factor, as well as the rest of factors, are above 0.3 (Hair et al., 1999).

\subsection{Scales}

For the USA sample, they have used the questionnaire developed by et al.(1998). For the Spanish one, the Spanish version of that same questionnaire was used (Marin-Garcia, 2002; Marin-Garcia et al., 2008). Those polled people were asked to evaluate the degree in which each of the high-involvement practices were being used at their sites. Each one of the variables was measured using a scale from 1 to 7 with the following equivalencies: 1 ( $0 \%$ of the employees take part in these activities or programs), 2 (1\%-20\%), $3(21 \%-40 \%), 4$ $(41 \%-60 \%), 5(61 \%-80 \%), 6(81 \%-99 \%), 7(100 \%$ of employees). Afterwards, the answers were recodified creating a scale from $1(0 \%-20 \%)$ to $5(81 \%-100 \%)$ in order to have equal range intervals. In the questionnaire, 9 rewards programs as well as 7 empowerment programs (table 2) have been included.

\subsection{Sample description}

We have used the data coming from field studies done in USA (Lawler III, Mohrman \& Benson, 2001; Lawler III et al., 1998) and in Spain (Marin-Garcia et al., 2008).

Spanish data were recorded in 1997 and they come from a random sample of 861 industrial companies from the list of Production Promotion, which includes the 2500 biggest Spanish companies (from those, 1259 were industrial establishments). The number of answers received was of 105 ( $12 \%$ answer rate). From these, 63\% came from the human resources manager and the remaining $37 \%$ from other high level directors.

USA data were gathered from Fortune 1000 list, which represents the biggest companies of the country. In the survey from 1999, 143 answers were received (15\% answer rate). Approximately half of them came from industrial companies and the rest from service companies. From all the answers, 44\% came from the human resources manager, and the remaining 66\% from other high level directors. In that from 1996, 212 replies were recorded (22\% answer rate). Roughly, half were production companies and the rest service ones. From these answers $45 \%$ came from HR directors and the remaining $65 \%$ from high level directors.

\section{Results, analyses and discussion}

In tables 8 and 9, we present the descriptive statistics of the values of both rewards and empowerment practices variables in the three data samples. We can observe how USA data maintain a certain similitude in the degree of use of empowerment and rewards programs in the two sets of years. However, we can also appreciate how some of the programs slightly increase in their level of use, whereas some of them decrease. Nevertheless, the degree of use of rewards programs in Spain is very different from that of USA (some programs are more 
used in Spain and others in USA). Moreover, empowerment programs in Spain, except in quality circles and work enrichment, are less used than in USA.

\begin{tabular}{|c|r|r|r|r|r|r|r|r|r|}
\hline \multirow{2}{*}{ Item code } & \multicolumn{3}{|c|}{ Spain 1997} & \multicolumn{3}{c|}{ USA 1996 } & \multicolumn{3}{c|}{ USA 1999 } \\
\cline { 2 - 11 } & Average & $\begin{array}{c}\text { Standard } \\
\text { Deviation }\end{array}$ & $\mathrm{N}$ & Average & $\begin{array}{c}\text { Standard } \\
\text { Deviation }\end{array}$ & $\mathrm{N}$ & Average & $\begin{array}{c}\text { Standard } \\
\text { Deviation }\end{array}$ & $\mathrm{N}$ \\
\hline Rem2 & 2.28 & 1.661 & 105 & 1,40 & 0,925 & 209 & 1,33 & 0,716 & 139 \\
\hline Rem3 & 1.55 & 1.315 & 105 & 2.70 & 1.829 & 211 & 2.55 & 1.748 & 140 \\
\hline Rem4 & 1.52 & 1.202 & 105 & 1.40 & 1.023 & 210 & 1.53 & 1.166 & 140 \\
\hline Rem5 & 1.97 & 1.404 & 105 & 2.19 & 1.405 & 209 & 2.39 & 1.397 & 140 \\
\hline Rem6 & 1.80 & 1.403 & 105 & 1.82 & 1.263 & 206 & 2.12 & 1.472 & 139 \\
\hline Rem7 & 1.72 & 1.411 & 105 & 3.31 & 1.595 & 212 & 3.64 & 1.599 & 142 \\
\hline Rem8 & 1.18 & 0.782 & 105 & 3.13 & 1.904 & 208 & 3.15 & 1.866 & 140 \\
\hline Rem9 & 1.33 & 0.967 & 105 & 3.10 & 1.868 & 205 & 3.34 & 1.847 & 141 \\
\hline Rem10 & 2.26 & 1.824 & 105 & 1.58 & 1.274 & 210 & 1.49 & 1.193 & 141 \\
\hline
\end{tabular}

Table 8. Rewards Practices

\begin{tabular}{|l|r|r|r|r|r|r|r|r|r|}
\hline \multirow{2}{*}{$\begin{array}{l}\text { Item } \\
\text { code }\end{array}$} & \multicolumn{3}{|c|}{ Spain 1997 } & \multicolumn{3}{c|}{ USA 1996 } & \multicolumn{3}{c|}{ USA 1999 } \\
\cline { 2 - 11 } & Average & $\begin{array}{c}\text { Standard } \\
\text { Deviation }\end{array}$ & $\mathrm{N}$ & Average & $\begin{array}{c}\text { Standard } \\
\text { Deviation }\end{array}$ & $\mathrm{N}$ & Average & $\begin{array}{c}\text { Standard } \\
\text { Deviation }\end{array}$ & $\mathrm{N}$ \\
\hline Part1 & 2.25 & 1.680 & 105 & 2.49 & 1.590 & 210 & 2.56 & 1.610 & 141 \\
\hline Part2 & 1.72 & 1.334 & 105 & 3.38 & 1.702 & 210 & 3.56 & 1.646 & 140 \\
\hline Part3 & 1.89 & 1.287 & 105 & 1.94 & 1.073 & 208 & 1.77 & 1.096 & 142 \\
\hline Part4 & 1.99 & 1.369 & 105 & 1.52 & 0.941 & 209 & 1.36 & 0.749 & 141 \\
\hline Part5 & 2.04 & 1.386 & 105 & 2.36 & 1.337 & 209 & 2.20 & 1.240 & 139 \\
\hline Part7 & 1.22 & 0.832 & 105 & 1.46 & 0.957 & 211 & 1.43 & 0.938 & 140 \\
\hline Part8 & 1.30 & 0.878 & 105 & 1.47 & 0.855 & 209 & 1.44 & 0.838 & 142 \\
\hline
\end{tabular}

Table 9. Empowerment Practices

Once the corresponding analyses were done, the estimations of the factorial loads were significant. But most of the times, their values were below 0.6. In table 10, we present the results of the confirmatory factorial analysis of model $1 a, 1 b, 2 a, 2 b, 2 c$ and $2 d$, for all three sets of data (Spain 97, USA 96 and USA 99). We can observe that, excepting 1b model for Spain 97 sample, the proposed models do not pass convergent validity tests. Even though some of the models present adjustment statistics globally good in some of the samples (even model $2 c$ has very good adjustment values for all three samples), practically most of them have an insufficient Cronbach $\alpha$, most of them do not pass compound reliability test, and none of them have and acceptable extracted variance. The only one that fulfills the requirement of simultaneously passing two validity criterions is model $1 \mathrm{~b}$ in the Spanish sample. In this case, we have performed discriminant validity tests. Even confidence interval tests is passed $(\rho=0.653$, S.D. $=0.176)$, explained variance test has been failed because the squared correlation between rewards and empowerment scales (0.426) goes highly beyond the extracted variance of each one of the two scales $(0.17 ; 0.28)$.

To sum up, none of the possible suggested models in literature have completely passed the measurement model validity test. On the other hand, we have observed that factorial loads in 
each of the analyzed samples are very different from one another and within a same model. That is to say, an additional problem, which is the lack of metrical invariance of the measurement models in the analyzed samples, appears (Steenkamp \& Baumgartner, 1998; Vandenberg \& Lance, 2000). It seems us interesting to highlight that the lack of metrical invariance is not only produced by comparing American samples with Spanish ones. It also occurs between the two American samples that have been obtained by the same group of researchers, with the same questionnaire and within a similar context.

\begin{tabular}{|c|c|c|c|c|c|c|c|c|c|c|c|}
\hline Model & $\begin{array}{l}\text { Chi2 } \\
\text { signif }\end{array}$ & $\begin{array}{l}\text { Chi2 / } \\
\text { d.f. } \\
\end{array}$ & CFI & IFI & MFI & GFI & RMSEA & $\alpha$ & Reliability & $\begin{array}{l}\text { Extracted } \\
\text { variance }\end{array}$ & $\begin{array}{l}\text { No. Of fulfilled } \\
\text { criterions }^{\text {a }}\end{array}$ \\
\hline $1 a-E S P 97$ & .000 & 2.32 & .64 & .668 & .843 & .887 & .113 & .649 & .656 & .17 & (2) 0 \\
\hline 1 a - USA 96 & .002 & 1.95 & .73 & .751 & .941 & .944 & .067 & .447 & .357 & .13 & (4) 1 \\
\hline 1 a - USA 99 & .153 & 1.27 & .91 & .920 & .974 & .952 & .044 & .580 & .547 & .16 & (7) 1 \\
\hline 1b - ESP 97 & .011 & 2.05 & .88 & .883 & .932 & .929 & .101 & .723 & .726 & .28 & (3) 2 \\
\hline $1 \mathrm{~b}-$ USA 96 & .005 & 2.20 & .91 & .914 & .961 & .962 & .076 & .642 & .678 & .25 & (6) 1 \\
\hline $1 b$ - USA 99 & .001 & 2.51 & .87 & .879 & .929 & .928 & .103 & .654 & .721 & .28 & (3) 1 \\
\hline $2 a-\operatorname{ESP} 97^{1}$ & .000 & 2.59 & .57 & .603 & .815 & .882 & .124 & .472 & .694 & .23 & (2) 0 \\
\hline $2 a-$ USA $96^{1}$ & .000 & 2.33 & .62 & .652 & .918 & .936 & .080 & .074 & .458 & .15 & (4) 1 \\
\hline $2 a-$ USA $99^{1,2}$ & .004 & 1.85 & .72 & .742 & .920 & .932 & .077 & .191 & .645 & .21 & (4) 1 \\
\hline $2 b-E S P 97$ & .661 & 0.75 & .99 & .999 & .999 & .979 & .000 & .560 & .562 & .20 & (7) 1 \\
\hline $2 b-U S A 96$ & .022 & 2.15 & .85 & .865 & .976 & .971 & .074 & .369 & .445 & .20 & (4) 1 \\
\hline $2 b-$ USA 99 & .175 & 1.41 & .94 & .947 & .987 & .972 & .054 & .591 & .588 & .21 & (7) 1 \\
\hline $2 c-E S P 97^{3}$ & .058 & 2.83 & .93 & .938 & .983 & .973 & .133 & .661 & .665 & .33 & (6) 1 \\
\hline $2 c$ - USA 96 & .617 & 0.00 & .99 & .999 & .999 & .998 & .000 & .487 & .508 & .21 & (7) 1 \\
\hline 2c - USA 99 & .474 & 0.74 & .999 & .999 & .999 & .995 & .000 & .464 & .519 & .22 & (7) 1 \\
\hline $2 d-\operatorname{ESP} 97^{4,5}$ & .000 & 4.34 & .636 & .654 & .787 & .865 & .179 & .462 & .741 & .30 & (1) 1 \\
\hline $2 d-$ USA $96^{5}$ & .000 & 8.30 & .460 & .479 & .786 & .889 & .186 & .533 & .687 & .24 & (1) 0 \\
\hline $2 d-$ USA $99^{5}$ & .000 & 6.94 & .502 & .522 & .747 & .866 & .205 & .616 & .731 & .29 & (1) 1 \\
\hline
\end{tabular}

Table 10. Models adjustment indicators. ${ }^{a}$ In between brackets we show how many statistics from column chi2signif to RMSEA fulfill the recommended values in table 7 for the goodness adjustment. If at least, 4 out of the 7 adjustment statistics are appropriate, we will consider that goodness adjustment exists. The other number shows how many of the four global criterions (model adjustment, Cronbach alpha, compound liability and extracted variance) follows the model.

- As scale $2 a$ only has 3 items, we have put scales $2 a+2 b$ together for the analysis.

- In order to solve an indetermination problem, we have introduce the mistake (E22) instead of considering it. The used value $(1,480)$ comes from the same model and from the same variable (Rem10) used with USA 96 data.

- Correlation has been added between the factors in order to avoid an specification problem with the variable.

- In order to solve an indetermination problem, we have manually introduced the mistake (E25) instead of supposing it. The used value $(0,9495)$ is the average of USA96 factorial charges $(0,935)$ and USA99 $(0,964)$.

- As scale $2 \mathrm{~d}$ only has 3 items, we have put scales $2 d+2 c$ together for the analysis.

Due to the fact that original model have not been validated, an exploratory factorial analysis was carried out in order to detect if a more appropriate grouping of the items in different scales existed. 
With regards to rewards practices (table 11), we can observe that the analysis presents a three factors solution for two out of the three samples and 1 out of four factors for USA96 sample. Moreover it confirms a lack of soundness in adding the same variables around a single factor. At last, both the total extracted variance, and the factorial charges are very low. All this leads us to think that, measurement models derived from these solutions, would present both metrical invariance problems between the different samples and convergent and discriminate validity problems.

\begin{tabular}{|c|c|c|c|c|c|c|c|c|c|c|}
\hline \multirow[b]{2}{*}{ Code } & \multicolumn{3}{|l|}{ Spain 97} & \multicolumn{4}{|l|}{ USA 96} & \multicolumn{3}{|l|}{ USA 99} \\
\hline & $\mathrm{F} 1$ & $\mathrm{~F} 2$ & F3 & $\mathrm{F} 1$ & $\mathrm{~F} 2$ & F3 & F4 & $\mathrm{F} 1$ & $\mathrm{~F} 2$ & F3 \\
\hline Rem2 & .100 & .224 & .524 & .078 & .432 & .048 & .003 & .000 & .427 & .048 \\
\hline Rem3 & .028 & .164 & .004 & .013 & .069 & .067 & .477 & .184 & .101 & .436 \\
\hline Rem4 & .487 & .269 & .004 & .215 & .008 & .359 & .202 & .361 & .102 & .325 \\
\hline Rem5 & .557 & .040 & .329 & .600 & .020 & .132 & .132 & .535 & .084 & .205 \\
\hline Rem6 & .404 & .079 & .401 & .594 & .083 & .020 & .007 & .489 & .085 & .021 \\
\hline Rem7 & .545 & .163 & .015 & .250 & .306 & .327 & .073 & .487 & .271 & .077 \\
\hline Rem8 & .068 & .511 & .050 & .059 & .306 & .327 & .073 & .537 & .053 & .059 \\
\hline Rem9 & .215 & .451 & .139 & .234 & .098 & .011 & .378 & .473 & .136 & .045 \\
\hline Rem10 & .027 & .585 & .202 & .022 & .013 & .480 & .127 & .013 & .458 & .002 \\
\hline $\begin{array}{l}\text { Extracted } \\
\text { variance for } \\
\text { each factor }\end{array}$ & $13 \%$ & $12 \%$ & $10.5 \%$ & $11,09 \%$ & $6,79 \%$ & $6,14 \%$ & $6,00 \%$ & $18,28 \%$ & $6,50 \%$ & $4,14 \%$ \\
\hline $\begin{array}{l}\text { Total } \\
\text { extracted } \\
\text { variance }\end{array}$ & $36.31 \%$ & - & - & $30,01 \%$ & - & - & - & $28,91 \%$ & - & \\
\hline
\end{tabular}

Table 11. Exploratory factorial of rewards practices. In bold, those values above .30, that are only higher to that value in a single factor and that differ from more than 0.30 of the charges in other factors for the same variable

\begin{tabular}{|c|c|c|c|c|c|c|}
\hline & Spain 97 & & USA 96 & & USA 99 & \\
\hline Code & $\mathrm{F} 1$ & $\mathrm{~F} 2$ & $\mathrm{~F} 1$ & $\mathrm{~F} 2$ & $\mathrm{~F} 1$ & $\mathrm{~F} 2$ \\
\hline Part1 & .511 & .351 & .382 & .087 & .101 & .364 \\
\hline Part2 & .556 & .237 & .529 & .035 & .007 & .597 \\
\hline Part3 & .372 & .573 & .588 & .324 & .423 & .531 \\
\hline Part4 & .492 & .114 & .465 & .142 & .431 & .433 \\
\hline Part5 & .419 & .467 & .481 & .363 & .537 & .317 \\
\hline Part7 & .033 & .608 & .104 & .553 & .626 & .023 \\
\hline Part8 & .552 & .020 & .145 & .555 & .667 & .119 \\
\hline $\begin{array}{l}\text { Extracted } \\
\text { variance for } \\
\text { each factor }\end{array}$ & $20,45 \%$ & $15,84 \%$ & $24,49 \%$ & 5,97 & $28,94 \%$ & $7,83 \%$ \\
\hline $\begin{array}{l}\text { Total extracted } \\
\text { variance }\end{array}$ & $36,28 \%$ & - & $30,46 \%$ & - & $36,77 \%$ & - \\
\hline
\end{tabular}

Tabla 12. Exploratory factorial of empowerment practices. In bold, those values above .30 , that are only higher to that value in a single factor and that differ from more than 0.30 of the charges in other factors for the same variable 
If we observe empowerment practices (table 12), we will find a similar situation. It is true that the analyses present a two factors solution for all three samples, and that the assignment of variables to factors is a bit more consistent than in rewards practices. However, the total extracted variance, as well as the factorial loads are very low. This shows, once more, that the measurement models arising from these solutions, would present convergent and discriminate validity problems.

Further to our analyses, we consider that we have not been able to find grouping of items into factors that allows us to have a valid and reliable scale within empowerment and rewards categories. Similar results were found, on the one hand by Yu et al. (2000) for USA data sample, and on the other, Drehmer et al. (2000). Guerrero and Barraud-Didie (2004) also noticed that rewards practices can rarely be added to a scale.

\section{Conclusions}

Our goal was to check whether reflective models shown in literature for questionnaires derived from Lawler et al. (1991) could be validated. Within the used samples, it was not either possible to carry out such validation, or to make a proposal based on an exploratory factorial analyses.

Therefore, we consider it would be advisable to deal in a future research with the verification whether the measurement model is formative instead of reflective. Measurement model is not an aim in itself, but a tool in order to check structure models. Therefore, we can consider this research as a previous and essential step, in future investigations, to help us explain in detail why and how high-involvement practices affect on results achievements (Becker \& Huselid, 2006).

Parallel to the previous, we can continue the future research about the relationship between high-involvement practices and company results based on Lawler et al. scales (1991). However, we believe it would be convenient to carry out an adaptation of ad-hoc scales for each sample (in such a way that the measurement model is optimized and is valid for that sample but cannot be used for comparing with different researches), or to use particular items of empowerment and rewards practices instead of adding them to some pretended scales, whose reliability is more than questionable, at least in contexts such us that from Spain or USA.

In our opinion, our paper represents a contribution for the academic world. On the one hand, it identifies three questionnaire typologies used in the field of investigations of rewards and empowerment practices. On the other hand, we show that the point of view with which the scales of theses questionnaires have been treated has always been reflective. Moreover, this is one of the few papers that have checked the validity of the measurement model of questionnaires derived from Lawler et al. (1991), It has also checked that of rewards and 
empowerment practices, by using equation structural models. At last, it questions the validity of a single questionnaire with similar samples, of different years, and simultaneously, with samples from same years but from different countries.

The contribution for the professional world is not that clear. However, company can profit from the results of this research because it helps to define measurement models that will allow to check, more strictly, relationships between rewards and empowerment practices with some other interesting variables such us, for instance, business results or employees perceptions. On the other hand, questionnaires validity will allow companies to have measurement and good practices diagnosis tools that can be used either for internal benchmarking or for the comparison with reference groups of companies.

\section{Acknowledgement}

The work described in this paper has been supported by the project "CORSARI MAGIC DPI2010-18243" by the Ministerio de Ciencia e Innovación del Gobierno de España within the Program de "Proyectos de Investigación Fundamental No Orientada"

\section{References}

Authors cite1: Hide to ensure the integrity of the blind peer-review 2012Pub01/id

Authors cite2: Hide to ensure the integrity of the blind peer-review 2009I/id 2010J/id

Addison, J.T. (2005). The determinants of firm performance: Unions, works councils, and employee involvement/high-performance work practices. Scottish Journal of Political Economy, 52(3), 406-450. http://dx.doi.org/10.1111/j.0036-9292.2005.00351.x

Alliger, G.M., Tannembaum, S.I., Bennett, W., Traver, H., \& Shotland, A. (1997). A metaanalysis of the relations among training criteria. Personnel Pyschology, 50(2), 341-358. http://dx.doi.org/10.1111/j.1744-6570.1997.tb00911.x

Anderson, J.C., \& Gerbing, D. W. (1988). Structural Equation Modeling in Practice: A Review and Recommended Two-Step Approach. Psychological Bulletin, 103(3), 411-423. http://dx.doi.org/10.1037/0033-2909.103.3.411

Appelbaum, E., \& Batt, R. (1994). The new American work place: transforming work systems in the United States. Nueva York: ILR press.

Bagozzi, R.P. (1994). Structural Equation Models in marketing research: Basic principles. In R.P. Bagozzi (Ed.), Principles of Marketing Research, (pp. 317-385). Malden, MA: Blackwell Publishers. 
Barrett, R., \& Mayson, S. (2007). Human resource management in growing small firms. Journal of Small Business and Enterprise Development, 14(2), 307-320. http://dx.doi.org/10.1108/14626000710746727

Bayo Moriones, A., \& Merino Díaz de Cerio, J. (2002). Las prácticas de recursos humanos de alto compromiso: un estudio de los factores que influyen sobre su adopción en la industria española. Cuadernos de Economía y Dirección de la Empresa, (12), 227-247.

Becker, B.E., \& Huselid, M.A. (2006). Strategic Human Resources Management: Where Do We Go From Here? Journal of Management, 32(6), 898-925. http://dx.doi.org/10.1177/0149206306293668

Benson, G.S., Young, S.M., \& Lawler III, E.E. (2006). High-involvement work practices and analysts' forecasts of corporate earnings. k, 45(4), 519-537.

Bentler, P.M. (2002). EQS 6 Structural Equations Program Manual. Encino, CA: Multivariate Software, Inc.

Bou, J.C., \& Beltran, I. (2005). Total quality management, high-commitment human resource strategy and firm performance: An empirical study. Total Quality Management \& Business Excellence, 16(1), 71-86. http://dx.doi.org/10.1080/1478336042000309875

Boxall, P., \& Macky, K. (2009). Research and theory on high-performance work systems: progressing the high-involvement stream. Human Resource Management Journal, 19(1), 323. http://dx.doi.org/10.1111/j.1748-8583.2008.00082.x

Camelo, C., Martin, F., Romero, P.M., \& Valle, R. (2004). Human resources management in Spain: is it possible to speak of a typical model? International Journal of Human Resource Management, 15(6), 935-958. http://dx.doi.org/10.1080/09585190410001677250

Cohen, A. (1993). Organizational commitment and turnover: a meta-analysis. Academy of management Journal, 36(5), 1140-1157. http://dx.doi.org/10.2307/256650

Combs, J., Liu, Y., Hall, A., \& Ketchen, D. (2006). How much do high-performance work practices matter? A meta-analysis of their effects on organizational performance. Personnel Psychology, 59(3), 501-528. http://dx.doi.org/10.1111/j.1744-6570.2006.00045.x

Cox, A., Zagelmeyer, S., \& Marchington, M. (2006). Embedding employee involvement and participation at work. Human Resource Management Journal, 16(3), 250-267. http://dx.doi.org/10.1111/j.1748-8583.2006.00017.x

Coye, R.W., \& Belohlav, J.A. (1995). An exploratory analysis of employee participation. Group \& Organization Management, 20(1), 4. http://dx.doi.org/10.1177/1059601195201002 
Datta, D.K., Guthrie, J.P., \& Wright, P.M. (2005). Human resource management and labor productivity: Does industry matter? Academy of management Journal, 48(1), 135-145. http://dx.doi.org/10.5465/AMJ.2005.15993158

de Menezes, L.M., \& Lasaosa, A. (2007). Comparing fits of latent trait and latent class models applied to sparse binary data: An illustration with human resource management data. Journal of Applied Statistics, 34(3), 303-319. http://dx.doi.org/10.1080/02664760601004908

Delery, J. E. (1998). Issues of fit in strategic human resource management: Implications for research. Human Resource Management Review, 8(3), 289-309. http://dx.doi.org/10.1016/S1053-4822(98)90006-7

Drehmer, D.A., Belohlav, J.A., \& Coye, R.W. (2000). An exploration of employee participation using a scaling approach. Group \& Organization Management, 25(4), 397. http://dx.doi.org/10.1177/1059601100254005

Drummond, I., \& Stone, I. (2007). Exploring the potential of high performance work systems in SMEs. Employee Relations, 29(2), 192-207. http://dx.doi.org/10.1108/01425450710720011

Fornell, C., \& Larcker, D. (1981). Evaluating Structural Equation Models with Unobservable Variables and Measurement error. Journal of marketing research, 18(February), 39-50. http://dx.doi.org/10.2307/3151312

Gerhart, B., Wright, P.M., Mahan, G.C., \& Snell, S.A. (2000). Measurement error in research on human resources and firm performance: How much error is there and how does it influence effect size estimates? Personnel Psychology, 53(4), 803-834. http://dx.doi.org/10.1111/j.1744-6570.2000.tb02418.x

Geyskens, I., Krishnan, R., Steenkamp, J.B., \& Cunha, P.V. (2009). A Review and Evaluation of Meta-Analysis Practices in Management Research. Journal of Management, 35(2), 393-419. http://dx.doi.org/10.1177/0149206308328501

Gollan, P.J. (2006). High involvement management and human resource line sustainability. Handbook of Business Strategy, 7(1), 279-286. http://dx.doi.org/10.1108/10775730610618945

Guerrero, S., \& Barraud-Didier, V. (2004). High-involvement practices and performance of French firms. International Journal of Human Resource Management, 15(8), 1408-1423. http://dx.doi.org/10.1080/0958519042000258002

Guest, D.E. (1997). Human resource management and performance: a review and research agenda. International Journal of Human Resource Management, 8(3), 263-276. http://dx.doi.org/10.1080/095851997341630 
Guthrie, J., Flood, P., Liu, W., \& MacCurtain, S. (2009). High performance work systems in Ireland: human resource and organizational outcomes. International Journal of Human Resource Management, 20(1), 112-125. http://dx.doi.org/10.1080/09585190802528433

Guthrie, J.P. (2001). High-involvement work practices, turnover, and productivity: eviddence from New Zealand. Academy of management Journal, 44(1), 180-190. http://dx.doi.org/10.2307/3069345

Guthrie, J.P., Spell, C.S., \& Nyamori, R.O. (2002). Correlates and consequences of high involvement work practices: the role of competitive strategy. International Journal of Human Resource Management, 13(1), 183-197. http://dx.doi.org/10.1080/09585190110085071

Hair, J.F., Anderson, R.E., Tatham, R.L., \& Black, W.C. (1995). Multivariate data analysis. (40 ed.) New Jersey: Prentice Hall.

Hair, J.F., Anderson, R.E., Tatham, R.L., \& Black, W.C. (1999). Análisis de datos multivariante. (40 ed.) Prentice Hall.

Hunter, J., Schmidt, F., \& Jackson, G. (1982). Meta-analysis Cumulative research findings across studies. UMI.

Huselid, M. (1995). The impact of human resource management practices on turnover, productivity, and corporate performance. Academy of management Journal, 38(3), 635-672. http://dx.doi.org/10.2307/256741

Ichniowski, C., \& Shaw, K. (1999). The effects of human resource management systems on economic performance: An international comparison of US and Japanese plants. Management Science, 45(5), 704-721. http://dx.doi.org/10.1287/mnsc.45.5.704

Jackson, T., \& Dyer, C. (1998). Diagnóstico corporativo: una herramienta para alcanzar la excelencia. ( 1 ed.) Madrid: TGP Hoshin (PRODUCTIVITY PRESS).

Katou, A.A. (2008). Measuring the impact of HRM on organizational performance. Journal of Industrial Engineering and Management, 1(2), 119-142. http://dx.doi.org/10.3926/jiem.2008.v1n2.p119-142

Kaya, N. (2006). The impact of human resource management practices and corporate entrepreneurship on firm performance: evidence from Turkish firms. International Journal of Human Resource Management, 17(12), 2074-2090. http://dx.doi.org/10.1080/09585190601000204

Lawler III, E.E. (1991). High involvement Management. San Francisco: Jossey-Bass. 
Lawler III, E.E. (2005). From human resource management to organizational effectiveness. Human resource management, 44(2), 165-169. http://dx.doi.org/10.1002/hrm.20059

Lawler III, E.E., Mohrman, S., \& Benson, G. (2001). Organizing for high performance: employee involvement, TQM, reengineering, and knowledge management in the fortune 1000. The CEO report. San Francisco: Jossey-Bass.

Lawler III, E.E., Mohrman, S., \& Ledford, G. (1998). Strategies for high performance organizations: employee involvement, TQM, and reengineering programs in fortune 1000 coporations. San Francisco: Jossey-Bass.

Lin, W.B. (2006). The exploration of employee involvement model. Expert Systems with Applications, 31(1), 69-82. http://dx.doi.org/10.1016/j.eswa.2005.09.035

Long, R.J., \& Shields, J.L. (2005). Best practice or best fit? High involvement management and base pay practices in Canadian and Australian firms. Asia Pacific Journal of Human Resources, 43(1), 52-75. http://dx.doi.org/10.1177/1038411105050307

Lopez-Araujo, B., Segovia, A.O., \& Peiro, J.M. (2007). The job involvement modulating role in the relationship between stress and job satisfaction. Psicothema, 19(1), 81-87.

MacDuffie, J.P. (1995). Human Resource Bundles and Manufacturing Performance: Organizational Logic and Flexible Production Systems in the World Auto Industry. Industrial and Labor relations Review, 48(2), 197. http://dx.doi.org/10.2307/2524483

Macy, B.A., \& Izumi, H. (1993). Organizational change, design and work innovation: a metaanalysis of 131 North American field studies- 1961-1991. Research in organizacional Change and Development, (7), 235-313.

Marin-Garcia, J.A. (2002). La gestión participativa en las grandes empresas industriales españolas: grado de uso, resultados obtenidos y comparación internacional. Proquest Information and Learning, sección UMI (publication number: 3025050).

Marin-Garcia, J.A., Bonavia, T., \& Miralles Insa, C. (2008). The use of employee participation in the USA and Spanish companies. International Journal of Management Science and Engineering Management, 3(1), 71-80.

Marin-Garcia, J.A. \& Conci, G. (2009). Exploratory study of high involvement work practices: Identification of the dimensions and proposal of questionnaire to measure the degree of use in the company. Intangible Capital, 5(3), 278-300. http://dx.doi.org/10.3926/ic.2009.v5n3.p278$\underline{300}$ 
Mayson, S., \& Barrett, R. (2006). The 'science' and 'practice' of HRM in small firms. Human Resource Management Review, 16(4), 447-455. http://dx.doi.org/10.1016/j.hrmr.2006.08.002

Melian-Gonzalez, S. \& Verano-Tacorante, D. (2004). A new approach to the best practices debate: are best practices applied to all employees in the same way? International Journal of Human Resource Management, 15(1), 56-75. http://dx.doi.org/10.1080/098519032000157339

Murphy, K.S., DiPietro, R.B., \& Murrmann, S. (2007). A Proposed Research Agenda for the Refinement of the High Performance Work System Construct in the U.S. Restaurant Industry. International Journal of Hospitality \& Tourism Administration, 8(4), 99-116. http://dx.doi.org/10.1300/J149v08n04 05

Ooi, K.B., Arumugam, V., Safa, M.S., \& Bakar, N.A. (2007). HRM and TQM: association with job involvement. Personnel Review, 36(6), 939-962. http://dx.doi.org/10.1108/00483480710822445

Roberts, R., \& Hirsch, P. (2005). Evolution and revolution in the twenty-first century: Rules for organizations and managing human resources. Human resource management, 44(2), 171176. http://dx.doi.org/10.1002/hrm.20060

Schroeder, R.G., \& Flynn, B.B. (2001). High Performance Manufacturing. Global perspectives. New York: John Wiley and Sons.

Sila, I. (2007). Examining the effects of contextual factors on TQM and performance through the lens of organizational theories: An empirical study. Journal of Operations Management, 25(1), 83-109. http://dx.doi.org/10.1016/j.jom.2006.02.003

SLavin, R.E. (1986). Best-evidence synthesis: an alternative to meta-analysis and traditional reviews. Educational researcher, 15(9), 5-11.

Spreitzer, G.M. (1995). Psychological Empowerment in the Workplace - Dimensions, Measurement, and Validation. Academy of management Journal, 38(5), 1442-1465. http://dx.doi.org/10.2307/256865

Steenkamp, J.B.E.M., \& Baumgartner, H. (1998). Assessing measurement invariance in crossnational consumer research. The Journal of Consumev Research, 25(1), 78-90. http://dx.doi.org/10.1086/209528

Tari, J.J., Molina, J.F., \& Castejón, J.L. (2007). The relationship between quality management practices and their effects on quality outcomes. European Journal of Operational Research, 183(2), 483-501. http://dx.doi.org/10.1016/j.ejor.2006.10.016 
Ullman, J.B., \& Bentler, P.M. (2004). Structural Equation Modeling. In M.Hardy \& A. Bryman (Eds.), Handbook of Data Analysis (pp. 431-458). SAGE. http://dx.doi.org/10.4135/9781848608184.n19

Vandenberg, R.J., Richardson, H.A., \& .Eastman, L.J. (1999). The impact of high involvement work processes on organizational effectiveness: A second-order latent variable approach. Group \& Organization Management, 24(3), 300. http://dx.doi.org/10.1177/1059601199243004

Vandenberg, R.J., \& Lance, C.E. (2000). A Review and Synthesis of the Measurement Invariance Literature: Suggestions, Practices, and Recommendations for Organizational Research. Organizational Research Methods, 3(1), 4-70. http://dx.doi.org/10.1177/109442810031002

Verburg, R.M., Den Hartog, D.N., \& Koopman, P.L. (2007). Configurations of human resource management practices: a model and test of internal fit. International Journal of Human Resource Management, 18(2), 184-208. http://dx.doi.org/10.1080/09585190601102349

Williams, L.J. \& O'Boyle, J. (2008). Measurement models for linking latent variables and indicators: A review of human resource management research using parcels. Human Resource Management Review, 18(4), 233-242. http://dx.doi.org/10.1016/j.hrmr.2008.07.002

Wong, C.S., Law, K.S., \& Huang, G.H. (2008). On the Importance of Conducting ConstructLevel Analysis for Multidimensional Constructs in Theory Development and Testing. Journal of Management, 34(4), 744-764. http://dx.doi.org/10.1177/0149206307312506

Wood, S., Holman, D., \& Stride, C. (2006). Human resource management and performance in UK call centres. British Journal of Industrial Relations, 44(1), 99-124. http://dx.doi.org/10.1111/j.1467-8543.2006.00489.x

Wood, S. (1999). Human resource management and performance. International Journal of Management Reviews, 1(4), 367. http://dx.doi.org/10.1111/1468-2370.00020

Wood, S., \& de Menezes, L.M. (2008). Comparing perspectives on high involvement management and organizational performance across the British economy. The International Journal of Human Resource Management, 19(4), 639-683. http://dx.doi.org/10.1080/09585 $\underline{90801953673}$

Wood, S., Stride, C.B., Wall, T.D., \& Clegg C.W. (2004). Revisting the use and effectiveness of modern management practices. Human Factors and Ergonomics in Manufacturing, 14(4), 415-432. http://dx.doi.org/10.1002/hfm.20006 
Yang, C.C. (2006). The impact of human resource management practices on the implementation of total quality management: An empirical study on high-tech firms. TQM Magazine, 18(2), 162-173. http://dx.doi.org/10.1108/09544780610647874

Yu, C.S., Finegold, D., Lawler III, E.E., \& Cochran, D.S. (2000). Does cultural fit matter? The adoption and efectiveness of the employee involvement practices in China and the United States. Current Topics on Management, 5.

Zacharatos, A., Barling, J., \& Iverson, R.D. (2005). High-Performance Work Systems and Occupational Safety. Journal of Applied Psychology, 90(1), 77-93. http://dx.doi.org/10.1037/0021-9010.90.1.77

Zatzick, C.D. \& Iverson, R.D. (2006). High-involvement management and workforce reduction: Competitive advantage or disadvantage? Academy of management Journal, 49(5), 999-1015. http://dx.doi.org/10.5465/AMJ.2006.22798180

Journal of Industrial Engineering and Management, 2012 (www.jiem.org)

El artículo está con Reconocimiento-NoComercial 3.0 de Creative Commons. Puede copiarlo, distribuirlo y comunicarlo públicamente siempre que cite a su autor y a Intangible Capital. No lo utilice para fines comerciales. La licencia completa se puede consultar en http://creativecommons.org/licenses/by-nc/3.0/es/ 